аспект / Володимир Костянтинович Буряк.- Київ: Деміург, 2005.- 232 с. 3. Гончаренко С. У. Український педагогічний словник / Семен Устимович Гончаренко. Київ : Либідь, 1997. - 376 с. 4. Ильина Т. А. Структурно-системный подход к организации обучения / Т. А. Ильина. - Москва : Знание, 1982. - 72 с. 5. Козловська І. М. Дидактична інтегрологія : сутність, теоретичні основи, застосування / I. М. Козловська // Педагогіка i психологія. - 2001. - № 1.- С. 51-60. 6. Освітні технології : [навчально-методичний посібник] / [за ред. О. М. Пехоти]. - Київ : А.С.К., 2002. - 256 с. 7. Сова М. Філософськокульторологічні основи інтеграції знань / Маргарита Сова // Рідна школа. - 2002. - № 5. С. 33-36. 8. Шамова Т. И. Управление образовательными системами / Т. И. Шамова.Москва : Академия, 2003. - 384 с.

УДК 378.14:622.007.2

Микола Ступнік, Володимир Моркун, Зінаӥда Бакум, Вікторія Ткачук

\title{
КОНЦЕПЦІЯ ПІДГОТОВКИ ГІРНИЧОГО ІНЖЕНЕРА В СИСТЕМІ НЕПЕРЕРВНОЇ ОСВІТИ (ШКОЛА - ВНЗ - ПІДПРИСМСТВО)
}

Ступнік М. І., Моркун В. С., Бакум 3. П., Ткачук В. В. Концепція підготовки гірничого інженера в системі неперервної освіти (школа - ВНЗ - підприємство).

У статті розроблено концепцію підготовки гірничого інженера в системі неперервної освіти. Визначено етапи означеної підготовки: загальноосвітній заклад, вищий навчальний заклад, підприємство. Обгрунтовано значення профорієнтаційної роботи, дидактичні засади фахової підготовки майбутніх інженерів в умовах сучасного вишу, а також порушено проблеми адаптації випускників гірничих факультетів на підприємстві.

Ключові слова: підготовка гірничого інженера, система неперервної освіти, етапи підготовки гірничого інженера, організація профорієнтаційної роботи, фахова підготовка, адаптація гірничих інженерів на підприємстві.

Ступник Н. И., Моркун В. С., Бакум 3. П., Ткачук В. В. Концепция подготовки горного инженера в системе непрерывного образования (школа - вуз - предприятие).

В статье разработана концепция подготовки горного инженера в системе непрерывного образования. Определены этапы такой подготовки в общеобразовательном заведении, высшем учебном заведении, на предприятии. Обосновано значение профориентационной работы, дидактические основы профессиональной подготовки будущих инженеров в условиях современного вуза, а также рассмотрены проблемы адаптации выпускников горных факультетов на предприятии.

Ключевые слова: подготовка горного инженера, система непрерывного образования, этапы подготовки горного инженера, организация профориентационной работы, профессиональная подготовка, адаптация горных инженеров на предприятии.

Stupnik M. I., Morkun V. S., Bakum Z. P., Tkachuk V. V. The concept of a mining engineer training in the lifelong learning system (school - higher educational institution - enterprise).

In the article the concept of a mining engineer training in the lifelong learning system has been developed. The attention is focused on the fact that among urgent problems the effective training and professional development of mining engineers are of key importance because of a severe shortage of highly qualified mining professionals. Stages of training have been defined. They are general educational institution, higher educational institution, enterprise. The value of occupational guidance, didactic principles of future engineers training in the condition of modern university have been proved. The problems of adaptation of mining faculty graduates at the enterprise have been discussed.

The first stage in the system of mining engineer training is educational institutions where one of the main objectives is ensuring the social adaptation of students, their adjustment to real 
conditions of society, existing structure of social relations and activities, including work activity.

The occupational guidance as an important factor providing the involvement of prospective students to further training at mining faculties has been described. It includes not only the information about professions, but work activity requirements as well.

The next stage, the finding out didactic principles of mining specialists training in terms of higher education, should be considered. It is noted that the educational process is carried out at two levels. At the bachelor course students acquire knowledge of humanities, social-economic, mathematical, natural science and general professional disciplines. At the same time they study special disciplines (from the cycle of general engineering and practical training). The second stage, engineering training according to specialty, involves profound studying of mining laws, economics and management, mining and blasting safety, and their design using modern computer systems.

At the final stage in the system of mining engineer training the adaptation of mining faculty graduates in the conditions of the modern enterprise has been characterized. It is difficult for young specialists because it is connected with significant change of purpose, conditions of activity, social environment, status and roles.

Key words: preparation of a mining engineer, a system of continuous education, the stages of preparation of a mining engineer, the organization of vocational guidance, vocational training, adaptation of mining engineers in the company.

Соціальні зміни та процеси, що відбуваються в сучасному суспільстві, пов'язані 3 входженням України до Європейського освітнього простору. Однією 3 умов успішної інтеграції $\epsilon$ наявність таких рис, як компетентність, творчість, професіоналізм, гуманність у діяльності соціальних суб'єктів усіх сфер життя. Неабияка роль у цьому процесі належить закладам вищої освіти, завданням яких є підготовка висококваліфікованих фахівців, здатних до роботи в умовах глобалізації, стандартизації європейської освіти, інформаційного росту, конкуренції.

3-поміж завдань, які потребують сьогодні першочергового розв'язання, одне з чільних місць посідає ефективна підготовка та підвищення кваліфікації гірничих інженерів, оскільки відчувається гострий дефіцит висококваліфікованих фахівців гірничої справи (особливо для розвитку нових проектів). Окрім того, наразі відбувається інтеграція вітчизняної гірничої галузі у світовий ринок, що вимагає постійної роботи з мінімізації виробничих витрат, утримання й розширення ринків збуту в умовах жорсткої конкуренції.

У контексті вищезазначеного варто зосередити увагу ще й на таких проблемах: недостатній рівень підготовки випускників загальноосвітніх шкіл, промислових технічних училищ, коледжів, що перешкоджає відбору здібних учнів для подальшого навчання у ВН3; участь підприємств, конструкторських бюро, галузевих інститутів у підготовці молодих спеціалістів; слабка технічна та лабораторна база кафедр вишів; рівень підготовки спеціалістів із фахових та фундаментальних дисциплін; недостатнє володіння спеціалістами комп'ютерною технікою, іноземними мовами, навичками управління виробництвом у сучасних умовах; гостра нестача сучасної науково-технічної літератури та підручників (посібники й навчальні програми потребують уточнення та доопрацювання, особливо в економічному та інноваційному аспектах); обмеженість міжнаціональної співпраці навчальних закладів (організація форумів європейських масштабів, спільна робота «тематичних мереж», де беруть участь університетські асоціації.); фінансування науки й освіти за «залишковим принципом».

Відтак з урахуванням положень освітньо-професійної програми підготовки фахівців напряму «Гірництво», специфіки професійної діяльності цих фахівців, а також на основі здійсненного аналізу й узагальнення наукових досліджень щодо визначення структури індивідуальної підготовки фахівця, реалізація освітніх завдань можлива за умов дотримання вимог до підготовки гірничого інженера, які повинні грунтуватися на таких засадах: аналіз традицій та інновацій у науково-технічній і соціально-економічній сфері; прогнозування змістових та структурних змін гірничого виробництва, науки, а також освітніх потреб 
населення; дослідження процесів становлення економіки країни i напрямів розвитку регіональних економік; системне визначення мети та діяльності гірничого інженера; вивчення стану та динаміки ринку інженерної праці; урахуванні ролі особистісної організації кваліфікованого фахівця у формуванні інженерного мислення, саморозвитку та професійної творчості.

Необхідно враховувати й те, що система знань, яка визначає контент підготовки гірничого інженера, характеризується міцним природничо-науковим, математичним, світоглядним фундаментом, широтою міждисциплінарних системних знань про природу, суспільство, мислення, а також високим рівнем загальних та спеціальних знань, які забезпечують діяльність у проблемних ситуаціях i дозволяють розв'язувати завдання підготовки фахівців високого творчого потенціалу. Адже нині постає проблема забезпечення якості рудної сировини гірничих підприємств на рівні світових вимог.

Майбутній інженер у процесі діяльності виконує чотири основні виробничі функції: проектувальну, дослідницьку, формування яких розпочинається у блоці фундаментальної підготовки, організаційну і технологічну, які формуються переважно у блоці професійнопрактичної підготовки. Відповідно, інженер повинен володіти науково-дослідницькими методами розв'язання виробничих завдань, брати участь у проектувальній та винахідницькій діяльності; ураховувати рівень технічного прогресу, щоб керуватись не лише установленою практичною, а схилятись до новаторської позиції в інженерній діяльності; знати технологію і техніку проектно-конструкторської роботи та володіти різноманітними формами самоосвіти.

У зв'язку з цим потребує переосмислення та перегляду процес підготовки гірничих інженерів, постає завдання розроблення нової освітньої концепції, в основу якої покладено ідею неперервної освіти: школа - ВНЗ - підприємство. Окрім того, пропонована концепція зорієнтована на підготовку інженерів в умовах гірничодобувної галузі як наукоємного виробництва.

Периим етапом у системі підготовки гірничого інженера є загальноосвітні заклади, у яких одним з основних завдань є забезпечення соціальної адаптації учня, пристосування його до реальних умов суспільства, до сформованої структури суспільних відносин і діяльності, зокрема трудової. Надлишок фахівців, підготовка недостатньо кваліфікованих працівників, низька частка зайнятості випускників ВНЗ - усе це проблеми, пов'язані з неправильним вибором професії. Тому завдання сучасної школи зазвичай полягає в тому, аби допомогти молоді досягти певного освітнього рівня, сприяти та спонукати до вибору професійного заняття. Професійна орієнтація поступово стає елементом усієї кадрової політики і частиною двох взаємопов'язаних систем: неперервної освіти й ефективної зайнятості, про що йдеться в низці нормативних документів, які регламентують профорієнтаційну роботу серед молоді («Про затвердження Положення про професійну орієнтацію молоді, яка навчається»; «Про затвердження плану заходів з реалізації Концепції державної системи професійної орієнтації населення»).

Аналізуючи нормативні документи, матеріали Колегій Міністерства освіти і науки, зауважуємо, що проблема професійного самовизначення, професійної орієнтації та життєвих планів молоді- актуальна на сучасному етапі розвитку суспільства. Профорієнтаційна робота $є$ важливим чинником, що забезпечує залучення абітурієнтів до подальшого навчання в університеті, передбачає не тільки наявність інформації про професії, а й ознайомлення 3 вимогами, що висуваються до трудової діяльності, яка, у свою чергу, вимагає наявність різних якостей i властивостей особистості, для успішного оволодіння професією. Така робота - показник активної присутності факультету та кафедр в освітньому просторі, що стає одним із критеріїв управління якістю освіти.

В організації профорієнтаційної роботи доцільно керуватися принципами: доступність професійної інформації щодо навчання та працевлаштування; взаємозв'язок інтересів особистості й суспільства в межах ринкової економіки; можливості отримання профорієнтаційних послуг громадянами України та інших держав, відповідно до міжнародних угод; конфіденційність висновків профконсультацій тощо.

Окрім реалізації принципів, у профорієнтаційній роботі важливо виконувати низку 
завдань: дотримання Конституційних прав громадян на працю, вільний вибір професії відповідно до професійних інтересів, нахилів, здібностей, стану здоров'я тощо; розвиток особистості у процесі іiі професійного становлення; формування інтелектуального та трудового потенціалу; забезпечення системного підходу у сфері професійної орієнтації; розроблення засад (законодавчих, соціальних, економічних, інформаційних, матеріально-технічних, кадрових i фінансових) розвитку профорієнтації населення; вивчення міжнародного досвіду у сфері професійної орієнтації.

У формуванні готовності до обгрунтованого вибору професії необхідне надання учням психологічної, педагогічної й інформаційної підтримки.

1. Професійна інформація - (бесіди, семінари, лекції профорієнтаційного спрямування, організовувати екскурсії на підприємства гірничого комплексу, зустрічі 3 керівниками підприємств, молодими робітниками, які здобували освіту на гірничих факультетах; доцільним у такій роботі $є$ створення професіограм, рекламних проспектів вишів, гірничих підприємств.

2. Професійне виховання (організовувати предметні гуртки, факультативи, створювати групи за фаховими інтересами; сприятимуть професійному визначенню і шкільні тематичні вечори, клуби цікавих зустрічей тощо).

3. Профдіагностування - слід звернути увагу на медичні огляди учнів, що проводяться задля виявлення відхилень у фізичному розвитку і стані здоров'я, їх корекції та лікування. Школярів і їхніх батьків варто інформувати про можливі обмеження відповідно до медичних показань, з урахуванням установлених умов, специфіки й особливостей праці гірників.

Задля виявлення індивідуальних особливостей, професійних інтересів, схильностей слід проводити психодіагностичне тестування.

4. Профконсультація - доцільно вивчити професійні плани школярів через анкетування, провести індивідуальні бесіди профконсультантів 3 учнями, розробити рекомендації щодо вибору майбутньої професії відповідно до інтересів і можливостей школяра, шляхів її здобуття.

5. Професійний відбір передбачає розроблення методик відбору за професіями, виявлення в кандидатів на роботу протипоказань до професії, відбір учнів для навчання на відділеннях допрофесійної підготовки ПТНЗ, у НВК відповідно до профілів. професії.

6. Аналіз ринку праці. На ньому надається інформація про рівень затребуваності

Другий етап у системі підготовки гірничого інженера - вищі навчальні заклади різних рівнів акредитації.

Бурхливий розвиток науки і техніки на межі XX i XXI століть висуває широке коло питань, пов'язаних із проблемами підготовки майбутніх фахівців, особливо в галузі гірництва. У «Національній доктрині розвитку освіти України у XX ст.» зазначено, що основною метою та пріоритетами розвитку освіти є іï особистісна орієнтація, формування професіонала, забезпечення умов для його професійної самореалізації [1].

У процесі з'ясування дидактичних засад підготовки фахівців гірничого профілю в умовах університетської освіти слід ураховувати, що навчальний процес здійснюється за двома рівнями. На рівні бакалаврської підготовки студенти здобувають знання 3 гуманітарних, соціально-економічних, математичних, природничо-наукових та загальнопрофесійних дисциплін. Водночас вивчають спеціальні дисципліни (із циклу загальноінженерної та професійно-практичної підготовки). Другий етап - інженерна підготовка за фахом - передбачає поглиблене вивчення гірничого права, економіки та менеджменту, безпеки гірничих і підривних робіт, їх проектування, зокрема 3 використанням сучасних комп'ютерних систем.

Змістовий компонент навчального процесу повинен ураховувати загальні характеристики об’єктів гірничої справи, формалізованих в освітньо-кваліфікаційній характеристиці та освітньо-професійній програмі, відповідно, навчальні плани та робочі програми. Інтегрований зв'язок навчальних програм зі спеціальних дисциплін із загально- 
інженерними, раціональне співвідношення лекційних, практичних, лабораторних занять в освітньому процесі створює умови для системного засвоєння студентами навчального матеріалу.

Відтак добір навчального змісту й організація навчального процесу повинні здійснюватися на визначених сучасністю підходаx- основних стратегічних напрямах, які охоплюють усі компоненти системи навчання: його цілі, завдання і зміст, шляхи і способи їх досягнення, діяльність педагога і суб'єкта, технології навчання, критерії ефективності навчального процесу, систему контролю [2].

Спостереження і досвід роботи дають підстави стверджувати, що у підготовці гірничого інженера слід реалізовувати: 1) особистісно зорієнтований; 2) компетентнісний; 3) системний.

Найважливішими ознаками особистісно зорієнтованого навчання прийнято вважати багатоваріативність методик і технологій, уміння організувати навчання на різних рівнях складності, утвердження всіма засобами цінності емоційного благополуччя, позитивного ставлення до світу, тобто внутрішньої мотивації. Означений підхід може реалізовуватися, наприклад, через варіювання оновлених освітніх завдань: формування високого рівня професійної компетентності та мобільності, широкого світогляду, в основу якого покладено знання суміжних дисциплін, пов'язаних 3 основною спеціальністю галузей; розвиток високого творчого потенціалу, який реалізовується у творчому мисленні під час розв'язання складних інженерних завдань в інформаційному середовищі; формування установки на саморозвиток, здатності приймати відповідальні рішення, формування індивідуального стилю діяльності, уміння постійно навчатися; вивчення стану та динаміки ринку інженерної праці та інтелектуальної продукції на регіональному, міжрегіональному, національному та міжнародному рівнях; урахування ролі особистісної організації професіонала-інженера у формуванні мислення інженерного типу, у власному способі входження в інженерну культуру та професійну творчість тощо.

Отже, особистісно зорієнтований підхід забезпечує розвиток особистості, грунтуючись на виявленні індивідуальних особливостей студента як суб'єкта пізнання i предметної діяльності.

Низку освітніх інновацій і класичних підходів доповнює компетентнісний підхід. Його упровадження передбачає набуття студентами необхідних життєвих, або ключових, предметних, або галузевих компетентностей. У першому разі йдеться про діяльність, зокрема засвоєння певних умінь і навичок, над виконанням яких людина розмірковує й усвідомлює їх застосування в конкретній життєвій сфері; в іншому - компетентність поширюється на вужчу сферу, наприклад, у межах певної наукової дисципліни.

Компетентнісний підхід полягає у «зміщенні акценту з накопичування нормативновизначених знань, умінь і навичок до формування й розвитку в учнів здатності практично діяти, застосовувати індивідуальні техніки і досвід успішних дій у ситуаціях професійної діяльності та соціальної практики; перспективність компетентнісного підходу полягає у високій готовності випускника до успішної діяльності в різних сферах» [3, с. 73].

На засадах професійної компетентності грунтується визначення інженерноі компетентності майбутнього фахівия. Дослідники в царині інженерної освіти розглядають інженерну компетентність як наявність у фахівця фундаментальної бази; освітню інженерну компетенцію як уміння поєднувати теорію з практикою; інженерну освіченість як знання соціальних, економічних і культурних умов, що виявляються на виробництві; інженерну підготовленість випускника ВНЗ як уміння фахівця пристосовуватися до технологій, що постійно змінюються, і умов у суспільстві; інженерний дослід фахівця як уміння ефективно використовувати засоби у міжособистісній комунікації [4, с. 10].

Означений підхід більш відповідає умовам ринкового господарювання, оскільки передбачає орієнтацію на формування поряд із професійними знаннями, уміннями та навичками (що для академічного підходу - основне), володіння професійними технологіями , розвитком таких універсальних здібностей (ключових компетенцій), як затребувані сучасним 
ринком праці.

Інтерес до системності досліджуваних об'єктів $€$ нині однією 3 основних методологічних настанов у багатьох царинах науки. Дослідження різних систем відбувається в межах системного підходу, завданням якого $\epsilon$ розроблення методів дослідження $\mathrm{i}$ конструювання складних за організацією об'єктів як систем.

3 огляду на це гірничий інженер повинен мати глибокі знання фундаментальних наук, досконало знати техніку i технологію, володіти прийомами технічного креслення та обчислювальною технікою, вільно орієнтуватися в економіці й організації виробництва [5].

У контексті реалізації системного підходу у процес підготовки гірничого інженера доцільно взяти до уваги перетворення інженерної освіти у сферу засвоєння пізнавальної та інженерної діяльності, що докорінно змінює уявлення про ВНЗ. Важливим напрямом розвитку інженерної освіти $\epsilon$ спеціальна організація роботи студента упродовж всього навчання в комплексних полідисциплінарних практико-зорієнтованих колективах, органічне залучення студентів до активної творчої діяльності, забезпечення їх масової участі в науково-дослідній роботі, створення цілевизначальних форм навчання. Усе це створює передумови переходу в інженерній освіті від навчально-освітнього до науково-освітнього процесу.

Сучасні розвідки в царині педагогіки вищої школи грунтуються передовсім на принщипах навчання- «системі вихідних положень, які визначають зміст, організаційні форми та методи навчальної роботи відповідно до загальної мети виховання i закономірностей процесу навчання» [6].

Отже, принципи навчання виражають закономірність процесу навчання, a ïx дотримання - необхідна умова успіху професійної діяльності майбутнього гірничого інженера. Принципи тісно пов'язані між собою і реалізуються в навчальному процесі в нерозривній єдності. Недотримання хоч би одного з них ускладнить реалізацію інших, призведе до зниження загальної ефективності навчання.

Сучасні підходи до освіти вимагають переосмислення сутності та завдань навчання, тому нині гостро стоїть потреба в переорієнтації на застосування адекватних до поставленої мети методів навчання.

Варто надати перевагу тим методам навчання, які сприяють формуванню вмінь без сторонньої допомоги оволодівати знаннями і $\epsilon$ надійною базою самоосвіти та умовою розвитку гармонійної особистості. Концепція розвивального навчання не переобтяжує пам'ять механічним заучуванням, спонукає до самостійності мислення, критичного аналізу матеріалу, є досить актуальною в педагогіці.

Для підготовки гірничих інженерів доцільно обрати класифікацію методів за типом (характером, рівнем) (І. Лернер, М. Скаткін): пояснювально-ілюстративний (інформаційнорецептивний); репродуктивний; проблемний виклад; частково-пошуковий, або евристичний метод; дослідницький.

Отже, у системі підготовки гірничих інженерів в умовах університетської освіти важливо враховувати дидактичні засади, які передбачають визначення змісту освіти, провідних підходів, принципів та методів навчання, що сприятиме здобуттю необхідних знань задля формування професійної компетентності майбутнього фахівця.

Нормативно-правова база стратегічних шляхів науково-технологічного розвитку презентована низкою законів України: «Про інноваційну діяльність», «Про державні цільові програми», «Про пріоритетні напрями розвитку науки і техніки», «Про спеціальний режим інноваційної діяльності технологічних парків» тощо.

Незважаючи на підвищений інтерес до питання розвитку національної інноваційної системи в гірничій галузі, нині все ще не сформовано державну інноваційну політику, яка ураховувала б накопичений світовий досвід формування інноваційної структури і була адаптована до вітчизняної дійсності. Відповідно, під час упровадження інновацій у гірничий промисловий комплекс, на думку науковців [7; 8; 9] варто брати до уваги низку чинників:

1) виснаження багатих родовищ із простими гірничо-геологічними умовами в 
доступних соціально-економічних освоєних регіонах;

2) межа зростання продуктивності під час застосування інноваційних технологій;

3) амортизація основних фондів (мова йде не тільки про фізичне зношення, а й про моральне старіння, зокрема гірничої техніки та обладнання;

4) низька екологічність низки об’єктів, зокрема за вищевказаними чинниками зносу основних фондів тощо.

Усі означені чинники потрібно враховувати й у підготовці сучасного гірничого інженера, який у подальшій професійній діяльності зможе упроваджувати інноваційні технології в гірничій галузі. 3 огляду на це посилюється увага до інноваційних систем не лише в технологічному, але і в педагогічному дискурсі. Освітні технології передбачають інноваційні моделі побудови такого навчального процесу, де на перше місце висувається взаємопов'язана діяльність викладача та студента, спрямована на розв'язання як навчального, так і практичного завдання. Такі моделі доцільно використовувати у підготовці гірничих інженерів, упроваджуючи інноваційні технології: інформаційно-комунікаційні, проектні, дослідницькі.

Стратегічними завданнями сучасної освіти, визначеними в «Національній доктрині розвитку освіти», законах України «Про вищу освіту», «Про Національну програму інформатизації», «Про основні засади розвитку інформаційного суспільства в Україні на 2007-2015 роки» $\epsilon$ створення умов для використання інформаційно-комунікаційних технологій (IКТ) у навчально-пізнавальній діяльності студентів, що сприяє ефективному розв'язанню комплексу проблем із підготовки фахівців загалом і гірничих інженерів зокрема.

Методи проектування і планування гірничих робіт не завжди відповідають повною мірою сучасним умовам господарювання. Однією з причин є низький рівень інформатизації в гірництві не дозволяє комплексно врахувати ці чинники, що призводить до заміни точних розрахунків приблизними, відсутності багатоваріантного аналізу, прорахунків та неконтрольованих втрат у виробництві. Слід пам'ятати ще й те, що сучасна шахта - це складна мережа гірничих виробок, для провітрювання яких застосовують найчастіше кілька джерел енергії і цілий комплекс вентиляційних споруд різного типу. До того ж повинні бути враховані як нормативні, так і аварійні умови роботи, внаслідок чого суттєве значення мають розрахунок і вибір ефективних режимів роботи в гірничих виробках. Розв'язання такого завдання без застосування ІКТ майже не можливе. Ефективність гірничих робіт, особливо на підприємствах, залежить від повноти аналізу геологічних даних про родовище корисних копалин. Основу цих обрахунків складають відомості про масив розкривних порід, просторове розміщення i розподіл корисної копалини в межах кар'єрного поля, гідрогеологічні умови залягання руд, можливості видобування і транспортування на гірничопереробні підприємства. Досвід свідчить, що лише повноцінний оперативний аналіз геологічних даних із використанням сучасних IКТ дозволяє досягти максимальної економічної ефективності гірничого виробництва за мінімальних втрат мінеральної сировини. Підвищення ефективності роботи гірничовидобувних підприємств в умовах ринкової економіки, підвищення виробничої і фінансової діяльності вимагає розроблення, освоєння і впровадження сучасних інформаційних технологій, що дозволяють комплексно представити гірничо-геологічну інформацію на основі геологічних моделей родовища i цифрових планів рельєфу місцевості, автоматизувати підрахунок запасів і календарне планування гірничих робіт. Відповідно, інформатизація процесу підготовки майбутнього гірничого інженера $є$ нині актуальним завданням.

Підсумовуючи сказане вище, доречно виокремити переваги гірничих комп’ютерних технологій: повне використання геологічної інформації у розв'язанні низки завдань, максимально точний облік руху запасів мінеральної сировини; можливість багатоваріантних розрахунків розвитку гірських робіт і отримання оптимальних стратегічних рішень, що дають великий економічний ефект; організація автоматизованої системи контролю й управління якістю руди; автоматизація створення будь-яких графічних матеріалів.

Сучасне суспільство ставить перед освітою нові вимоги до підготовки фахівця, 
здатного бути не лише висококваліфікованим виконавцем, носієм певних знань, а й активним учасником будь-якого процесу, у якому необхідно самостійно вибудовувати свою життєву і професійну стратегію. Ці завдання можуть бути розв'язані за допомогою проектної діяльності - пізнання дійсності, завдяки якому особистість послуговується технологічними, технічними, економічними та іншими знаннями [10].

Гірничодобувна галузь $є$ пріоритетною в сучасній економіці України, а реалізація інноваційних проектів - значущим чинником створення необхідних умов підготовки конкурентоспроможного гірничого інженера на світовому ринку праці.

Підготовка гірничого інженера в умовах компетентнісної парадигми освіти потребує упровадження проектної технології в рамках системного підходу.

I курс - залучення студентів до участі в науково-практичних конференціях, наукових семінарів, участі в засіданнях круглого столу тощо. Така діяльність допоможе визначитися 3 постановкою проблеми для подальшого iï розв'язання в майбутньому проекті. Для ефективної організації проектної діяльності студента на цьому етапі на кафедрі визначається науковий керівник, який закріплюється за кожним студентом, і керує упродовж усіх років навчання.

II курс - обрання напряму проектної діяльності відповідно до наукових шкіл кафедри, визначення мети і завдань дослідження; відображення його результатів у межах курсового проектування. Відповідно до поставленої мети студенти вивчають проблему на основі аналізу наукових публікацій, що забезпечує більш усвідомлене бачення досліджуваної проблеми, обирають технології виконання, здійснюють відбір необхідних методів та їх аналіз;

III курс - проходження виробничої практики, під час якої створюється можливість отримання зворотного зв'язку з безпосередніми споживачами науково-освітніх продуктів (організація перевірки та тестування наукових розробок на базі партнерських організацій). Студенти розробляють практичні аспекти проблеми, що мають виражений прикладний характер. Реалізація цих практичних аспектів вимагає від студентів залучення знань з різних предметів, творчого і логічного мислення, дослідницьких аналітичних і проектувальних умінь і навичок.

IV курс - опублікування результатів дослідження в українських та зарубіжних виданнях, відображення ключових позицій у кваліфікаційній роботі. На цьому етапі важливим завдання учасників проекту знайти партнера або клієнта для реалізації продукту.

$\mathrm{V}$ курс - виконання дипломного проекту, у якому відображено напрацювання з певної проблеми, а також реалізація продукту.

Сучасна освіта потребує свого вдосконалення в напрямку розвитку і реалізації дослідницької діяльності студентів, на що вказують нормативно-правові документи, які регламентують функціональність вищої школи. Так, у Постанові Кабінету Міністрів України «Про затвердження положення про державний вищий навчальний заклад освіти» та Законі України «Про освіту» 3-поміж основних позицій розвитку процесу навчання названо науково-дослідну діяльність студентів як складник підготовки фахівців, створення умов для самореалізації особистості. Такі положення закріплено і в Законі України «Про вищу освіту».

Науково-дослідницька діяльність студентів організовується у вищих навчальних закладах 3 урахуванням Державної цільової науково-технічної та соціальної програми «Наука в університетах», розробленої Міністерством освіти і науки України, у якій зазначено, що НДР студентів у межах навчального плану є обов'язковою для кожного суб'єкта навчання [11]. Вибір конкретних форм і видів науково-дослідницької роботи студентів, обсягів навчально-дослідних завдань і часу на їх виконання не може бути довільним, а грунтуватися на докладному аналізі навчальних програм і планів.

Дослідницька діяльність студентів вишів здійснюється за напрямами: 1) навчальнодослідницька, яка є невід'ємним елементом навчального процесу та входить до календарнотематичних і навчальних програм як обов'язкова для всіх студентів; 2) науково-дослідницька робота, що виконується поза навчальним процесом у межах студентського науково-творчого 
товариства.

Третім етапом у системі підготовки гірничого інженера є адаптація випускників гірничих факультетів в умовах сучасного підприємства, яка для молодих фахівців вирізняється особливою складністю, оскільки пов'язана з істотною зміною мети, характеру, умов діяльності, соціального оточення, статусу і ролей.

Процедура адаптації складається 3 трьох послідовних блоків: уведення нового співробітника в корпоративну культуру, адаптація до службових обов'язків та моніторингу ефективності адаптації.

Етап 1. Ознайомлення з корпоративною культурою. Процес адаптації співробітників єдиний для всіх спеціальностей. На цьому етапі молодого фахівця ознайомлюють із підприємством. Входження фахівця в колектив починається з ознайомлення із внутрішнім трудовим розпорядком, нормами роботи, комунікації в колективі тощо.

Етап 2. Вступ до спеціальності. Новий співробітник під керівництвом наставника починає виконувати конкретні робочі завдання.

Етап 3. Моніторинг ефективності адаптації. За підсумками випробувального терміну відділ розвитку персоналу отримує документи (таблиця, у якій вказані всі процедури адаптації співробітника і час їх виконання; звіт наставника, де подана пропозиція: приймати нового співробітника на постійну роботу чи ні; опитування нового фахівця). Учень, у свою чергу, оцінює роботу наставника і надає відділу розвитку персоналу відгук про клімат у колективі.

Управління адаптацією гірничого інженера $\epsilon$ можливим за умови володіння наставником базою знань з організації й управління виробничою діяльністю в сукупності зі знанням інженерно-педагогічних аспектів (динаміки механізму адаптації; особливостей навчання дорослих; ключових аспектів наставництва; мотивації в наставницькій діяльності; форм впливу на підлеглого; особистісних чинників, що сприяють ефективності порозуміння наставника та працівника-початківця; психофізіологічних особливостей сприйняття, пам'яті, мислення, уваги, мовлення дорослих тощо).

Отже, ключова проблема, на розв'язання якої спрямована ідея концепції підготовки гірничого інженера, полягає у здобутті фундаментальних знань, формуванні умінь і навичок, що забезпечують подальшу можливість застосовувати знання спочатку в навчальній, а в перспективі й у професійній діяльності. Освітній процес презентуємо як систему творчих майстерень авторитетних науковців, провідних інженерів, студентів, здобувачів бакалаврських, магістерських ступенів та інженерних звань, аспірантів і докторантів, які створять творчий колектив, відповідну наукову школу, де реалізується наступність у методології пізнавальної діяльності, цінностях і меті інженерної роботи.

\section{Література}

1. Про Національну доктрину розвитку освіти : Указ Президента України [Електронний ресурс]. - Київ : 17.04.2002. - № 347/2002. - Режим доступу : http://zakon1.rada.gov.ua/laws/show/347/2002 2. Абрамчук О. Процес виховання студентів університету в позаурочний час / О. Абрамчук, О. Федун // Молодь і ринок. - 2009. - № 9. С. 32-36. 3. Паращенко Л. I. Технологія формування ключових компетентностей у старшокласників: практичні підходи / Л. І. Паращенко // Компетентнісний підхід у сучасній освіті: світовий досвід та українські перспективи ; за заг. ред. О. В. Овчарук. - Київ : К. І. С., 2004. - С. 73-86. 4. Белоновская И. Д. Формирование профессиональной компетентности специалиста: региональный опыт / И. Д. Белоновская. - Москва : Ин-т развития профессионального образования, 2005. - 351 с. 5. Кирпичев В. Л. Задачи высшего технического образования / В. Кирпичев. - Львов - Харьков, 1890. - 24 с. б. Олійник П. М. Дидактичні принципи навчання та їх дидактико-методичні особливості // Методика навчання і наукових досліджень у вищій школі : П. М. Олійник, С. У. Гончаренко, К. Федорченко та ін.; за ред. С. У. Гончаренка, П. М. Олійника. - Київ : Вища шк., 2003. - С. 55-68. 7. Stupnik N. I. Influence of rock massif stress-strain state on uranium ore breaking technology / N. I. Stupnik; V. A. Kalinichenko; M. B. Fedko; Ye. G. Mirchenko // Scientific Bulletin of National 
Mining University. - 2013. - Issue 2. - Р. 11. 8. Моркун В. С. Оптимизация управления качеством железорудной продукции на основе ультразвукового контроля / В. С. Моркун, O. В. Поркуян // Научный журнал «Материалы IV Международной конференции «Стратегия качества в промышленности и образовании».- Болгария- Варна, Технич. ун-т, 2009. C. 143-147. 9. Купін А. I. Інтелектуальна ідентифікація та керування в умовах процесів збагачувальної технології : [монографія] / Андрій Іванович Купін. - Кривий Ріг : КТУ. 2008. - 204 с. 10. Концепція державної програми роботи з обдарованою молоддю на 20062010 роки // Освіта України. - 2006. - № 48 (741). - С. 1-3. 11. Державна цільова науковотехнічна та соціальна програма «Наука в університетах» на 2008-2012 роки [Електронний pecypc]/ Кабінет Міністрів України. - Офіц. вид. - Київ, 2007. - Режим доступу : http://zakon1.rada.gov.ua

УДК 378.937

Анжселіка Татарнікова

\section{ПЕДАГОГІЧНІ УМОВИ ФОРМУВАННЯ ПРОФЕСІЙНОЇ КОМПЕТЕНТНОСТІ СТУДЕНТІВ МУЗИЧНИХ СПЕЦІАЛЬНОСТЕЙ 3 АРТ-МЕНЕДЖМЕНТУ}

Татарнікова А. А. Педагогічні умови формування професійної компетентності студентів музичних спеціальностей з арт-менеджменту.

У статті на основі аналізу й узагальнення концептуальних підходів зарубіжних та українських науковців щодо сутності навчальних програм 3 арт-менеджменту, а також модернізації мистецької освіти, обгрунтовано педагогічні умови формування професійної компетентності студентів музичних спеціальностей 3 арт-менеджменту. Продемонстровано значущість професійної підготовки студентів музичних спеціальностей як майбутніх артменеджерів, розкрито дидактичний потенціал провідних принципів i засобів компетентнісного й студентоцентрованого підходів щодо ii організації й оцінки якості прикінцевих результатів.

Ключові слова: арт-менеджмент, професійна компетентність 3 арт-менеджменту, компетентнісний підхід, студентоцентрований підхід, фахова підготовка студентів музичних спеціальностей.

Татарникова А. А. Педагогические условия формирования профессиональной компетентности студентов музыкальных специальностей по арт-менеджменту.

В статье на основе анализа концептуальных подходов зарубежных и украинских ученых к исследованию сущности учебных программ по арт-менеджменту, а также модернизации художественного образования, обоснованы педагогические условия формирования профессиональной компетентности студентов музыкальных специальностей по арт-мененджменту. Продемонстрирована значимость профессиональной подготовки студентов музыкальных специальностей как будущих арт-менеджеров, раскрыт дидактический потенциал ведущих принципов и средств компетентностного и студентоцентрированного подходов к ее организации и оценке качества результатов.

Ключевые слова: арт-менеджмент, профессиональная компетентность по артменеджменту, компетентностный подход, студентоцентрированный подход, профессиональная подготовка студентов музыкальных специальностей.

Tatarnikova A. A. Pedagogical conditions of professional competence development of music students in Arts Management.

This article comprises the substantiation of the pedagogical conditions of professional competence development of music students in Arts Management based on the analysis of the conceptual approaches of foreign and Ukrainian scientists to educational programmes' research in Arts Management, as well as the modernisation of professional music education system. The importance of the vocational training of music students who are to become Arts Managers is also 